\title{
THE INTELLECTUAL AND SPIRITUAL CONTRIBUTION OF NURUDDIN AR-RANIRI TO ISLAMIC EDUCATION IN INDONESIA
}

\author{
Mwamburi Adam Hamisi \\ Faculty of Islamic Revealed Knowledge and Human Sciences \\ International Islamic University Malaysia, Gombak, Malaysia \\ Jalan Gombak, 53100 Kuala Lumpur, Selangor, Malaysia
}

\author{
AbdulGafar Olawale Fahm \\ Department of Religions, University of Ilorin, Ilorin, Nigeria. \\ 1515, Unilorin Staff Quarters, Amodu Bello Way, Ilorin, Nigeria \\ Email: fahm.ao@unilorin.edu.ng
}

Received: 07, 2017. Accepted: 12, 2017. Published: 12, 2017.

\begin{abstract}
This paper attempts to analyze the intellectual and spiritual contributions of Nuruddin ar-Raniri to Islamic education in Indonesia. It gives the genealogy of ar-Raniri and his arrival to Indonesia as well as the vital role he played in the documentation of important literatures in Malay and Islamic education. This paper further argues that Nuruddin ar-Raniri, serving as a Sufi scholar, great writer, theologian, historian has immense contribution. His impact and influence in Indonesia was profound and noteworthy. His contribution to Malay literature and Islamic education is unavoidable. His masterpieces on intellectual writings has exerted considerable effort in the field of Malay letters and historical writings. His writings cover various fields of knowledge which helped in developing the learning culture in the society. This study used a qualitative approach in collecting and analyzing the data. This study concludes that due to this great contribution in the field of Islamic knowledge, arRaniri emerged as an exceptional scholar of his time and a pioneer in the standardization of Islamic religious text within Indonesia. Thus, it remains a legacy and a significant contribution in transforming Indonesia spiritually and intellectually. His contribution in Islamic education includes learning material and Islamic traditional book delivered in Pegon language which used in pesantren and other Islamic education institutions in Indonesia.
\end{abstract}

Keywords: Indonesia, Intellectual, Islam, Islamic Education, Nuruddin ar-Raniri, Spiritual.

\begin{abstract}
ABSTRAK
Penelitian ini bertujuan untuk. menganalisis kontribusi intelektual dan spritiual dari tokob terkemuka Nuruddin arRaniri, di Indonesia. Pembahasan dimulai dari genealogi ar-Raniri dan kedatangannnya ke Indonesia dan juga peran pentingnya yang belian mainkan dalam penulisan literatur Islam dalam babsa Melayu dan pendidikan Islam. Penelitian ini menunjukan babwa Nuruddin ar-Raniri memberikan kontribusi yang sangat besar dalam kapasitasnya sebagai teolog, sejarawan dan ilmuwan sufi. Dampaknya terbadap Negara Indonesia layak dikaji. Kontribusi terbadap perkembangan literatur Melayu tidak bisa diabaikan. Karya-karya besar beliau telah mewarnai perkembangan literatur Melayu dan penulisan sejarahnya. Karya tulisnya mencakup banyak hal dan bidang pengetahuan di dalam negara yang sedang berkembang. Penelitian ini menyimpulkan babwa Nuruddin ar-Raniri memberikan kontribusi yang besar dalam bidang pengetabuan Islam. Ar-Raniri juga tampil sebagai ilmunvan bebat dalam bal standarisasi teks keagamaan Islam di Indonesia. Sementara kontribusi beliau dalam bidang pendidikan setidaknya terdapat dalam dua aspek, yaitu aspek, materi pembelajaran dan penulisan berbagai kitab kuning dalam bahasa Jawi (Arab Melayu) yang digunakan diberbagai lembaga pendidikan Islam di Indonesia.
\end{abstract}

Kata Kunci: Indonesia, Intelektual, Islam, Pendidikan Islam, Spiritual, Nuruddin ar-Raniri. 


\section{INTRODUCTION}

The arrival of Islam to Malay Peninsula was recorded as early as $12^{\text {th }}$ century on the North Coast of Sumatra. Malik al-Salih was the first Muslim ruler of Pasai died in 1297. In 1380, Pasai and Kedah were under the kingship of a Muslim royal family (Winstedt, 1969). Therefore, Malay Kingdoms played a dominant and leading role in the spread of Islam and Islamic mysticism in the Malay Peninsula. By 1416, the Chinese found that the Sumatran people of Aru, Samudra, Pidir, and Lambri were all Muslims (Winstedt, 1969). Around 1409, Malaca embraced Islam and its ruler got married to a Pasai Princess. In 1475, inhabitants of the Coast of Java were already Muslim. By 1511, Palembang and Sunda people also accepted Islam. Meanwhile, around 1521 it is documented that Brunei was already engaging nonMuslims in its territory (Winstedt, 1969).

The observation clearly shows the influence of Islam in South East Asia, which emerged as early as $13^{\text {th }}$ Century. The rapid influence and spread of Islam were facilitated largely by its adaptability and toleration as well as the intermarriage between the Muslim merchants from Arabian Peninsula, Persia, India and local inhabitants (McAmis, 2002). Moreover, a lot of jurisprudence, theology, and sufism scholars have been appeared in Malay peninsula during the $16^{\text {th }}$ and $17^{\text {th }}$ Century (Fakhry, 1997). Among the most famous and prominent personalities involved in the propagation of Islam are as follow: 1) Hamza Fansuri; 2) Nuruddin ar-Raniri; 3) Shamsuddin al-Sumatrani; and 4) Abdurrauf al-Singkeli (M. N. S. AlAttas, 1970; Fakhry, 1997).

Nuruddin ar-Raniry was a great scholar and occupied an important position in the Sultanate of Aceh Daarussalam. His influence on the spread of Islam in Indonesia, especially in Aceh and his contributions to the teachings of Islam and sufism in Aceh were so tremendous. He has a good command on tasawwuf, aqidab, tafsir, fiqh and religion comparative study. Furthermore for kālam and tasawuf field, he eloquently quoted Imam al-Ghazali, Ibn 'Arabi, al-Qunyawi, al-Qasyani, al-Fairuzabadi, al-Jilli, 'Abd ar-Rahman al-Jami', Fadhlullah alBurhanpuri, and other prominent scholars. There are four main points of his thought which telling about God, nature, people and Wujudiyyah (Madjid, 2015). In the field of jurisprudence, he showed his mastery to refer to standard Shafi'i books such as Minhäj at-Thälibin, anNawawi's works, Fath al Wahhäb, Syarb Minhäj at-Thulläb, by Zakariyya al-Anshari, Hidàyat alMubtäj Syarh al-Mukbtashar by Ibn Hajar, al-Anwār by al-Ardabili or Nibāyat al Mubtäj (Ila Syarb al-Minhäj; Nawawi's work) by Syamsuddin ar-Ramli (Muzakkir, 2009, p. 47).

$\mathrm{He}$ also devoted himself for the sake of Islam development when the sultanate of the Acehnese granted him authority to spread Islam knowledge. He was deeply attracted to the world of Melayu. After accomplishing his knowledge seeking trip in the Middle East, he returned to Aceh in 1637 AD. He received trust from the Sultan of Alexandria as Shaykh alIslam. Having received a strong position in Aceh, ar-Raniri started campaigning radical Islamic renewal.

Generally, ar-Raniry was known as a persistent figure who rejected the teachings of Sufism developed by Hamzah Fansuri. This Sufism was known as pantaisme and was better known as the "wahdat al-wujud". In contrast, ar-Raniry brought the notion of "wahdat AsSyuhud". Both figures were so central and very influential in Aceh. Their debate occured because of their difference in understanding of sufism. The debate between them was so popular so that many people assumed that their greatest contribution was renewal in the field of Sufism itself. Heterodox Sufism was realized by Hamzah Fansuri and Syamsuddin alSumatrani thoughts. Meanwhile, Ortodox Sufism was realized by Nuruddin ar-Raniri and Abdurrauf al-Singkeli thoughts (Masrur, 2017). The thoughts of Indonesian scholars take an important role related to its' relevance with religion life and current Indonesian culture (Ismail, 2016). 
The influences of Nuruddin ar-Raniri is really wide spread throughout Indonesia included his contribution in the field of education. Despite his high position in the sultanate of Aceh Daarussalam serving as Shaykh al-Islam, he did not forget his duty to teach. In previous studies conducted by experts, Arraniry contribution in Islamic education has not been extensively discussed among researchers. Therefore, this research seeks to raise the contribution of Ar-Raniry in the field of Islamic education in addition to his contribution in the development of Islam in Indonesia, especially in the field of intellectual and spiritual.

\section{METHOD}

This study is qualitative in nature. It employed literature review to gain the data concerning the intelectual and spiritual contribution of Nuruddin Arraniri to Islamic education. In order to obtain the data about the contribution of ar-Raniry toward Islamic education, there are several steps conducted: 1) exploring various resources either journal article or book relating to the main thought of ar-Raniry in any field; 2) analyzing deeply various educational aspects assumed to be the main support of ar-Raniri; and 3) stating arRanniri contributions to Islamic education world.

\section{DISCUSSION}

This section features several section to deal with the objectives of this study. It elaborates first the life and intellectual career of Nuruddin Arraniri. In the end of this section the contribution of Nuruddin Arraniri to Islamic education.

\section{Nuruddin Ar-Raniri's Early Life}

Nuruddin ar-Raniri came from an Arab family, tracing its descendant from Quraish (M. N. AlAttas, 1986). He was born in Raniri in Gujarati. Since the $16^{\text {th }}$ century, ar-Raniri family had always maintained close contact with Pahang and Aceh in the Malay Peninsula as his mother was a Malay. Between 1580-1583, Ar-Raniri paternal uncle, Muhammad Al-Hamid arrived in Aceh to teach logic, rhetoric, ethics, figh, science of the sources and other religious and intellectual subjects (M. N. Al-Attas, 1986), but came to realize that he could not influence and generate interest in these subjects as much as in mysticism (M. N. Al-Attas, 1966). Ar-Raniri belonged to the Shafi ' $i$ school of law, branch of the Sunni school, which is the sole school of Islamic law in the Malay world, and Ash'ariyyah school of theology and Rifa'iyyah tariqa of Sufis. He was initiated and introduced to Rifa'iyyah tariqa by Sayyid Abu Hafs Umar Ibn Abdi'llah Ba Shaiyban of South Arabian origin (Hadhramawt) (M. N. Al-Attas, 1966).

Ar-Raniri arrived in Malay Peninsula around 1637 and stayed in Pahang and Aceh where he mastered Malay language and literature. This greatly facilitated his mission in disseminating his message to the Malay world. ar-Raniri emerged as a prominent scholar, at the court of Iskandar Tsani, he was later elevated him to the highest religious office and referred as Shaikh al-Islam (M. N. Al-Attas, 1966). Ar-Raniri's appointment as Sheikh al-Isläm also got him involved in dealing with heretical Wujüdiyyah mystics and this resulted in a debate against the proponents of the deviating Wujudiyyah, this happened around the time he arrived in Aceh. Ar-Raniri stated this as regards the debate:

When a group of the deviating and strayed Wujuidiyyah from among the disciples of the misguided Shamsuddin al-Sumatrani. I made their appearance, they engaged us in debate for several days in the presence of the Sultan....In order to refute their erroneous words and vain belief, I composed a short treatise in exposition of the claim of the shadow and the possessor of the shadow....you claim for yourselves divinity in the same manner as did Pharaoh, who said I'm your lord most high, nay you are indeed an unbelieving people (M. N. Al-Attas, 1966). 
Ar-Raniri through his debate with Wujüdiyyah proponents led to a gradual process of correction in the understanding and interpretation of the sufi doctrines and metaphysics. This made ar-Raniri emerged as one of the leading pioneers in the interpretation of sufi doctrines within Indonesia (M. N. Al-Attas, 1966; Bidin, 2009; Nur, 2013). That is why al-Raniri is positioned by some scholars as a popular figure in contrast to Hamzah Fansuri and Syamsuddin as-Sumatrani and as one of the pioneers of Islamic reformer in Malay-Indonesian archipelago. His anti-Wujuidiyyah sufism campaign was quite successful in opposition to the philosophical sufism brought by Fansuri and Sumaterani (Nur, 2013).

\section{Ar-Raniri's Intellectual Works}

As a Muslim scholar in the 17th century, Syeikh Nuruddin ar-Raniri contributed in the various fields of knowledge. He was a well-known scholar identified with other famous Scholars of Nusantara such as Syeikh Daud al-Fatani, Syeikh Abdul Samad al-Palimbani and others (Abd. Rahman, 2006). It is important to state here that in the field of hadith, he was considered as the first Muslim scholar of Nusantara that produced book al-Fawä'id al-Bähiyyah fì al-Ahädith alNabawiyyah in Jawi font (Abd. Rahman, 2006).

Ar-Raniri also played a vital role in documenting the extremely needed literature in Malay and Arabic language on principles of Islam which never existed before, the early missionaries of Islam conveyed the teaching Islam by oral instruction and practical application and taught masses how to conduct themselves according to the basic tenets of Islam. Due to this, ar-Raniri produced a substantial number of polemics writings regarding marriage and divorce entitled; as-Shirät al-Mustaqim, and Bäb an-Nikäh which were studied in areas such as Kedah in about 1640 (M. N. Al-Attas, 1966). Other works written by him include: Durrat alFaräidh bi Sharb al-Aqäid, it deals with spiritual and intellectual teachings; Hadiyyat al-Habì fì alTarghib wa al-Tarbib, a concise synopsis selected from traditions of prophet Muhammad; Nubdha fi Da'wa al-Zill ma'a Shähibibi, this is about refutations against the deviants and pseudoSufis; Lathäif al-Asrär, it explains the beliefs of sufi doctrine; Asrär al-Insān fì Ma'rifat al-Rūh wa al-Rahman, it outlines the manner of addressing the issue of enhancing spiritual ethics; Tibyan $f i$ Ma'rifat al-Adyan, this deals with the expositions of religions and the clarification of understanding different religious beliefs and sects and consequently puts a clear cut between the true and false beliefs; Akhbär al-Âkhira fi Ahwäl al-Qiyamah, the work discusses the stories of the hereafter regarding the events of the resurrection day, basically it elaborates what will happen in the hereafter and the situation during the day of doom; Hall al-Zill, it deals with the nature of the world and its understanding according to sufi doctrines; Ma' al-Hayat li $\mathrm{Abl}$ alMamät; 'Umdat al-I'tiqäd, this is an exposition of the articles of beliefs; Syifä al-Qulüb; Hujjat alSiddiq li daf' al-Zindiq, it is a distinction, clarification and a refutation against pseudo-Sufis, philosophers, and deviant theologians; Durr al-Farä'id bi Sharh al-Aqä'id among the earliest work of al-Raniri and proves that he loomed as a member of kalam and involved in the educational programs in Indonesia. It highlights theological views and covers various dimensions such as epistemology, ontology, syariah, and siyasab symbolizing the comprehensive nature of Malay Islamic thought (Wan Daud \& Muammar, 2009). Fath alMubin 'ala al-Mulbidin; al-Lam'ān fì Takfir man Qäla bi Khalq al-Qur'ān; Syawärim al-Siddìq li Qath'i al-Zindiq; Rahiq al-Muhammadiyyah fì Thariq al-Süfiyyab; Bad' Khalq al-Samāwat wa al-Ardh, this work explains the beginning of the creation and earth; Kaifiyyat al-Shalät; al-Shirät al-Mustaqim, it deals with Fiqh al-Ibādat, practical religious practices pertaining to devotional duties. It became a reliable textbook for schools especially in the traditional religious learning centers (Harun, 2009). It is considered one of the oldest works on the Malay language ever known in South East Asia. It was once regarded as an authoritative work in figh in Malay Archipelagoes particularly in Aceh. It deals with matters pertaining to only Ibadat (Hashim \& Ali, 2008). 
Among his most famous works is Bustän al-Salätīn. The full title of the book is; Bustän alSalatin fi Driker al-Awwalin wa al-Akbirin [The Garden of the Kings on the Recollection of Past and Present]. This is an encyclopedia which consists of seven chapters which covers variety of subjects like creation of the world, stories of the prophets (Qashas al-Anbiy a) and kings (Ropi, 1999; Steenbrink, 1990), just kings and wise ministers, ascetic rulers and pious saints, unjust rulers and oppressive ministers, stories of generous and dignified personalities, brave men and victors of battle of Badr and Uhud, various kinds of science including Physiognomy and Medicine etc. (Harun, 2009). This book is regarded as the most important exposition on early Malay history and its features and style of led to the development of Malay historiography in the seventeenth century. As a result, the impact of Islam in Indonesia was real especially in transforming the 'body', the soul and mind of a different community in the area. Some contemporary writers like Al-Attas also view it as a significant and reliable legacy as well as a landmark in the reconstruction of the early history of Islam in the Malay world (Harun, 2009). Through this book, he proved to be a very excellent and competent historiographer (Harun, 2005).

In 1982, a study was conducted on the writings of Nuruddin ar-Raniri in Jakarta by a team of scholars from the Faculty of Art and Culture Universitas Gadjah Mada, Indonesia. In using several works of Nuruddin ar-Raniri such as Hujjat al-Siddiq li Daf'i al-Zindiq, Tibyan fi Ma'rifät al-Adyān, Hill al-Zhill, as-Shirät al-Mustaqim and Bustān al-Salätin, the researchers documented of various interesting values in the writing of al-Raniri (Musa, 2007). Some of which include: His narrative structures; style of discourse and language; rhetorical features; symbolism; mystical conception and ideas of Nuruddin ar-Raniri; the interconnectedness of his writings with other Malay traditional works such as Täj al-Salātin, Hikayat Aceh, Sejarah Melayu, Hikayat Iskandar Zulkarnain, Hikayat Hang Tuah, and Hikayat Sultan ibn Adam (Musa, 2007).

Other works of ar-Raniri published and compiled into bibliographical details in various catalogues since 1866 by Dutch scholars especially P. Voorhoeve are: Jawähir al- Ulüm fi Kashf al-Ma'lum (The Pearl of Knowledge to Uncover the Truth); Hidàyat al-İmàn fì Fadhl al-Mannān (The Guidance of Faith and the Bounty of the Benefactor); Aläqat Alläh bi al-Älam (The Relation between God and World); and Aqaìd al-Süfiyyah al-Muwabhidin (Sufis Aqida on the Oneness of God) (M. N. Al-Attas, 1986; Harun, 2009).

\section{Ar-Raniri's Intellectual and Spiritual Contributions}

One of the noble traditions in Indonesia is the tradition of teaching Islam as it appears in Javanese pesantren and similar institutions outside Java as well as the Malay Peninsula. The main reason for the emergence of this pesantren is to transmit traditional Islam as it is found in the classical books centuries ago.

Since the ancient times, from the era of the Islamic Kingdom of Samudera Pasai to the Islamic Kingdom of Aceh Darussalam, the Islamic educational institutions are called with dayah. The existence of dayah is believed to have existed since the entry of Islam in Aceh in the year 800 AD brought by traders who come from the Arabian Peninsula when anchored in the Coastal Region of Sumatra. In addition to trade, these traders are also active in spreading Islamic thought. To accelerate further the process of spreading Islamic thought, then dayah was established which at that time serves as a medium of transformation of Islamic education to the community. The term dayah name is often used specifically for the people of Aceh, but in general, dayah referred to a boarding school.

One of the famous scholar from Aceh is Nuruddin ar-Raniri. He can be regarded as the father of Islamization and standardization of Islam in Indonesia. This point becomes more poignant when we consider the narration that at a time the people of Malacca in $14^{\text {th }}$ century lost touch with the Islamic spirit or essence. It got to a point in which one could not 
distinguish between a Muslim and non-Muslim, Muslim men wedded Pagan wives, and the Muslim women married Pagans, divorce was not treated as a religious act, as there were no written laws governing marriage and divorce, Muslims consumed dog meat and drink wine in public places (M. N. Al-Attas, 1986). In this regard, ar-Raniri played a vital role in cleansing or clearing the minds of the people from doubts about Islam and from vices that is spreading roots in the hearts of the people. He produced various books explaining the basic tenets of Islam like Bäb al-Nikēh, Umdat al-Itiqäd, as-Shirät al-Mustaqim, etc. Ar-Raniri greatly contributed to the Islamization process and his impact was reflected and felt in most parts of Indonesia, this was achieved through his wise counseling of the Sultan and his court. One of the impacts of his prolific writings led to the banning of the occurrence of pagan practices by the Sultan (M. N. Al-Attas, 1969).

In 1638, he produced his encyclopedic work known as Bustān Al-Salätin, and this was a request from Sultan Iskandar Tsani. Through the text, he successfully produced an Islamic guide to the Malay rulers, explaining the proper duties of rulers to the people and country based on the Islamic principles and values (Steenbrink, 1990). Up to this point in time, Many rules and instructions of the work remain useful even in dealing with contemporary problems, especially in terms of Islamic moral values and perceptions (M. N. Al-Attas, 1969; Harun, 2009).

Ar-Raniri's thoughts had an enormous contribution to Indonesia in distinguishing between the true and false interpretation of sufi doctrines and metaphysics. He prepared a Malay translation of the best commentary on the Islamic creed through his classic book asShirät al-Mustaqim where he skillfully explained the basic tenets and essentials of Islam. He also streamlined the Malay judicial system through his Islamization and standardization concepts, by way of enacting concepts of Sharia on a basis of social order when he was appointed as a court advisor at Aceh. This great contribution facilitated in providing solutions to many legal disputes.

Nuruddin ar-Raniri through his works helped in transforming many aspects of preIslamic cultural practices and beliefs of the people by exploring deeply the Islamic worldview. As mentioned earlier, during his time there was no proper and reliable documentation of Islamic literature which could be used as a guide to the people when conducting their daily affairs like marriage, divorce, etc. (M. N. Al-Attas, 1966). He played an enormous role in the sphere of Islamic knowledge throughout Indonesia, and this contributed positively in unifying the Malay sultans and helped them in confronting Western imperialism during the advent of the colonial rule. The Intellectual contribution of ar-Raniri to Malay civilization played a significant role in providing the significant change that led to a stronger Islamic-based social order in Indonesia. Nuruddin ar-Raniri played a vital role in terms of spiritual and intellectual upliftment of the people by facilitating the establishment of new ground for social order through Islamic teachings and consequently adoption of Sharia. As a result, the impact of Islam in Indonesia was real especially in transforming the body, the soul and mind of different groups within the society.

In addition, through his book Tibyan fi Ma'rifat al-Adyan, he effectively exposited and clarified different religious beliefs and sects thereby attempt to make a clear cut between the true and false beliefs. He stood very firm against any beliefs and ideas which contradict and disagree with the belief of mainstream Islam.

\section{Ar-Raniri's Contribution on Islamic Education}

Finding a relationship between ar-Raniri and pesantren is not an easy task because there is a lack of studies investigating this issue. In addition there is not enough evidence supporting the relationship between ar-Raniri and pesantren. Despite the fact, Ar-raniri is closely related to pesantren world. In the context of Islamic education, Nuruddin ar-Raniri has made a very 
important change. The change was not on the institutional aspect, but on the subject matter of Islamic religion. Before ar-Raniri was present in Aceh, Islamic learning was more dominated by mysticism and Sufism delivered by Hamzah Fansuri with his Wujüdiyyah teachings. Hamzah Fansuri was the world's largest intellectual in Aceh. He was known as prolific writers who had produced many of the writings of religious writings that are full of mystical ideas. In arRaniri's view, what Hamzah Fansuri taught to the people of Aceh was very misleading to the Islamic faith.

Nuruddin ar-Raniri wrote his opinion about the misunderstanding Wujūdiyyah brought by Hamzah Fansuri. Some issues which had been discussed in his books are:

1. About God's that could be totally integrated (immanent) with nature. In ar-Raniri's view, Wujudiyah's understanding of the existence of the Gods added in the Incanbiyyah, Hulüliyah and Ittihädiyyah.

2. About nùr of Muhammad that came from a light before the creation of a creature, so they believed that all light was essentially the light of God. According to ar-Raniri the opinion was synonymous with the ideas of the philosophers, the Zoroaster, Tanāsukhiyah (reincarnation) and Hindu Brahmanism who believe in nūr (light).

3. About the Qur'an which was created creature. According to ar-Raniri, these accusations were identical to the Qaddafi, Mu'tazilah, the Makblīqiyah and the Lafdhiyah Jahmiyah and secte Karämiyah in a group of seventy publications.

4. About eternity of universe (qadim). According to ar-Raniri, the opinion was in contrast with Islamic belief, and categorized into Jahmiyah ism.

5. Ar-Raniri concluded that Wujudiyah's doctrine was similar to that of incarnation and reincarnation, embraced by the Ittibädiyyah, Hulüliyah, Tanäsukhiyah, and Hurriyah Sufi, Mushabbihah or Mujassimah (Hermansyah, 2014, p. 54-55; Madjid, 2015)

Based on the style of sufism thought developed by Hamzah Fansuri, ar-Raniri saw that people's belief in a straight Islamic creed became shaky and misguided. In addition, Wujüdiyyah mysticism is too dominant, making the jurisprudence and the basics of faith less taught. Therefore, in his renewal in the field of Islamic education, ar-Raniri introduced his new cheerleaders and religious ideas. Although the people of Wujüdiah and followers of Arabi, in their interpretation of the students' teachings, they rejected the jurisprudence and the jurisprudence. Wujudiyah understanding, which not only emphasizes the pressure of the king, but also explains the Muslim archipelago of the archipelago basic principles, the rules of religion, the comparison of religion, the importance of religion, history and religion. In order to explain all of these, he will interpret and arrest the books that discuss the readiness of their knowledge and their knowledge on the condition of Islam-at that moment. The outstanding books of Nurruddin ar-Raniri are: 1) Al-Shiräth al-Mustaqim (1634);2) Durrat al-fariid bi Syarh al-'Aqäid an Nasafiyah (1635); 3) Hidāyat al-babìb fi al Targhib wa 'l-Tarbï (1635); 4) Bustānus al-Sbalätbin fi dzilkr alAwwalin wa 'l-Äkbirin (1638); 5) Nubdzah fi Da'wa al-Zhill ma'a Shähibibi; 6) Lathäì al-Asrär; 7) Asräl anInsān fì Ma'rifat al-Rüh wa al-Rahmän; 8) Tibyän fi ma'rifat al-Adyän; 9) Akbbär al-Ākbirah fi Abwäl alQiyämab; 10) Hill al-Zhill; 11) Ma'u 'l-Hayät li Abl al-Mamät; 12) Jawähir al-'ulüm fi Kasyfi 'l-Ma'lüm; 13) Aina al-'Alam qabl an Yukblaq; 14) Syifä'u 'l-Qulüb; 15) Hujjat al-Shiddiq li daf'i al-Zindiq; 16) Al-Fat-bu 'lMubin 'ala 'l-Mulhiddin; 17) Al-Lama'in fi Takfir Man Qäla bi Khalg al-Qurān; 18) Shawārim al- Shiddĩ li Qath'i al-Zindiq; 19) Rabiq al-Mubammadiyyah fi Thariq al-Shüfiyyab; 20) Ba'dhu Khalg al-Samäwät wa 'l-Ardh; 21) Kaifiyat al-Shalät; 22) Hidāyat al-İmān bi Fadhli 'l-Manān; 23) 'Aqä̀id al-Shüfiyyät al-Munahbidīn; 24) 'Aläqat Allāh bi 'l-'Ālam; 25) Al-Fathu 'l-Wadūd fì Bayān Wabdat al-Wujūd; 26) 'Ain al-Jawwwäd fì Bayān Wabdat al-Wujüd; 27) Awdhah al-Sabil wa 'l-Dalil laisa li Abäthil al-Mulbiddin Ta'wili; 28) Awdhah al-Sabil laisa li Abäthil al-Mulbiddin Ta'will; and 29) Syadar al-Marid.

The book Bustan as-Salatin was composed based on the request from Sulthan Iskandar Tsani. It contains the issues concerning constitution of the state and history. It was a revised version of the previous book, Täj al-Salatinn (The Crown of the King) which was composed by 
Bukhari al-Jauhari. The book Bustān as-Salatìn discusses not only state constitution but also elaborates issues on the future of humankind (escatology), Fiqh, Tasawnf, and Ushül ad-Din. Because of its thickness, the book has not been published in its full version. It has been published in a smaller unit either a particular chapter or some chapters. It is paramount as a sourceful book on the Aceh history telling the story of Sulthan Iskandar Thani and royal park built since the reign of Sultan Iskandar Muda.

Nuruddin ar-Raniri's other contribution was his attempts to compose several book delivered in Malay language written in Malay Language (Jawi Language). His masterpieces and book Bustann as-Salatin were so famous that they were displayed and taught in several dayah/Pesantren spread throughout Aceh in the XVII century. His legacy made him popular figure and influential scholar in Aceh in his time. His legacy has attracted islamic sholars to discuss and investigate his books in their research. Other masterpieces that he wrote in Malay language were: 1) Al-Shiräth al-Mustaqim, concerns figh issues, 2) Durrat al-fariid bi Syarh al'Aqäid an Nasafiyah (1635), discusses aqìdah Islämiyah; and Syifä' al-Qulūb, elaborates methods of drikir. Books that are classified to Jawi have been an important part of archipelagic Islam history. Their existence have been very advantageous for Muslim in this archipelagic country. They have been serving as a subject of study and references for Islamic studies in Indonesia, Malaysia and Thailand. Those books which are frequently used namely: as-Siräth al-Mustaqim, written by Syekh Nuruddin ar-Raniri (Abu Bakar, 2016).

The book Bustain as-Salatin and other ar-Raniri's works were so popular that they adorn the books taught in dayahs/pesantrens that were widespread in Aceh in the seventeenth century. These facts made Nuruddin ar-Raniri the most influential educational figure in Aceh during the seventeenth century. The magnitude of ar-Raniri's contribution to Islam and the world of education attracted a number of experts to conduct studies on him.

\section{CONCLUSION}

Ar-Raniri is a Sufi scholar, great writer, theologian and historian. His contribution, impact, and influence in Indonesia were profound and tremendous. He actively contributed in the documentation of basic Islamic tenets, like theology, essentials of Islam, the Sharia law governing its pragmatic applications in moral and ethical principles both in Arabic language and Malay, making him a pioneer in this area. Due to his vast knowledge, he successfully made a distinction between the true and the false interpretation of Sufi theology. His extraordinary expository writings were all inclusive and covered variety of subjects such as marriage and divorce, food and drink, social and personal ethics, eschatology, comparative religion, Sufism, dualism, pantheism, and monism of pseudo-sufis and heretics of various sorts.

His contribution in Islamic education includes the writing of several basic issues in fiqh and the basic of Islamic foundation to reduce the dominance of tasawuf teaching brought by Hamzah Fansuri and Syamsudin al-Sumatrani. In addition his masterpiece written in Arabic pegon (Malay language which is written in Arabic) that responded to the need of the society at that time.

\section{BIBLIOGRAPHY}

Abubakar, M. (2016). Kitab Jawi dan kontribusinya dalam kajian Islam di Kepulauan Nusantara. Proceedings ARICIS: Ar-Raniry International Conferenece of Islamic Studies. Vol. 1. Retrieved from https://jurnal.ar-raniry.ac.id/index.php/aricis/article/view/964/771

Abd. Rahman, M. M. (2006). Syeikh Nuruddin al-Raniri dan sumbangannya kepada pengajian al-Hadith. Al-Bayan Journal of Al-Quran \& Al-Hadith, 4, 47-62. Retrieved from https://goo.gl/86JE5E 
Al-Attas, M. N. (1966). Rānirì and the wujüdiyyah of 17th century Acheh. Singapore: MBRAS by Malaysia Printers.

Al-Attas, M. N. (1969). Preliminary statement on a general theory of the Islamization of the MalayIndonesian Archipelago. Kuala Lumpur: Dewan Bahasa dan Pustaka.

Al-Attas, M. N. (1986). A Commentary on the Hujjat Al-Siddiq of Nur Al-Din Al Raniri. Ministry of Culture, Youth and Sports.

Al-Attas, M. N. S. (1970). The mysticism of Hamzah Fansuri. Kuala Lumpur: University of Malaya Press.

Bidin, M. E. (2009). Naẓarīyat al-Fanā’ fī al-Turāth al-Ṣūfī al-Indūnīsī: Dirāsah Taḥlìlīyah Studia Islamika: Indonesian Journal for Islamic Studies, 16(2), 303-322. Retrieved from http://journal.uinjkt.ac.id/index.php/studia-islamika/article/view/484/399

Bin Musa, H. (2007). A brief commentary on pantheistic school of mysticism as described inmemahami karya-karya Nuruddin Ar-Raniri. Jurnal Filologi Melayu, 15, 35-43.

Fakhry, M. (1997). A short introduction to islamic philosophy, theology and mysticism. England: One World Publication.

Harun, J. (2009). Bustan al-Salatin: A Malay mirror for rulers. Pulau Pinang: Penerbit Universiti Sains Malaysia.

Hashim, J., \& Ali, A. K. (2008). Kitab Al-Sirat Al-Mustaqim oleh Shaykh Nur Al-Din AlRaniri: satu sorotan. Jurnal Fiqh, 5, 197-216. Retrieved from http://erep.unisza.edu.my/810/

Hermansyah. (2014). Naskah Tibyan Fi Ma'rifat al-Adyan; interpretasi aliran sesat di Aceh menurut Nuruddin Ar-Raniry. Jumantara, 5(1), 54-55. Retrieved from http://www.pnri.go.id/magazine/naskah-tibyan-fi-marifat-al-adyan-interpretasi-aliransesat-di-aceh-menurut-nuruddin-ar-raniry/

Ismail. (2016). Falsafah wujudiyah Hamzah Fansuri Pemikiran dan pengaruhnya di dunia melayu nusantara. Manbaj: Jurnal Penelitian Dan Pengabdian Masyarakat, 4(3), 239-252. Retrieved from http://ejournal.iainbengkulu.ac.id/index.php/manhaj/article/download $/ 188 / 172$

Jelani Harun. (2005). Bustan Al-Salatin: Mutiara kesufian untuk raja-raja dari pada Nuruddin al-Raniri. Jumal Filologi Melayu, 13, 26-39.

Madjid, A. (2015). Karakteristik pemikiran Islam Nuruddin ar-Raniry. Jurnal Subtantia: Jurnal Ilmu-Imu Ushuluddin Dan Filsafat, 17(2), 179-190. Retrieved from http://substantiajurnal.org/index.php/subs/article/view/137/131

Masrur, A. (2017). Pemikiran tasawuf ortodoks di Asia Tenggara (telaah atas kontribusi alRanirî, al-Singkilî, dan al-Makasarî). Syifa Al-Qulub: Jurnal Studi Psikoterapi Sufistik, 1(2), 42-49. Retrieved from http://journal.uinsgd.ac.id/index.php/syifa-al-qulub/article/ view/1431/992

McAmis, R. D. (2002). Malay muslims: The history and challenge of resurgent Islam in Southeast Asia. Wm. B. Eerdmans Publishing.

Muzakkir. (2009). Studi Tasawuf; Sejarah, Perkembangan ,Tokobdan Analisis. Bandung: Cita Pusaka Media Perintis.

Nur, S. (2013). Kritik Terhadap Pemikiran Tasawuf Al-Raniri. Kanz Philosophia: A Journal for Islamic Pbilosophy and Mysticism, 3(2), 137-151. Retrieved from https://www.researchgate.net/publication/295829734_Kritik_Terhadap_Pemikiran_Ta sawuf_Al-Raniri

Ropi, I. (1999). Muslim responses to Christianity in modern Indonesia. ProQuest Dissertations and Theses. McGill University.

Steenbrink, K. A. (1990). Jesus and the holy spirit in the writings of Nur al-Din al-Raniri. Islam and Christian-Muslim Relations. https://doi.org/10.1080/09596419008720934 
Wan Daud, W. M. N., \& Muammar, K. (2009). Kerangka komprehensif pemikiran melayu abad Ke-17 Masihi berdasarkan manuskrip Durr Al-Fara'Id karangan Sheikh Nurud AlRaniri. International Journal of the Malay World and Civilisation, 27(2), 119-146. Retrieved from http://journalarticle.ukm.my/1184/1/SARI27\%5B2\%5D2009_\%5B06\%5D.pdf

Winstedt, R. (1969). A history of classical Malay literature. (Y. A. Talib, Ed.) (1992nd ed.). Malaysian Branch of the Royal Asiatic Society. 